\title{
EFFECT OF FEEDING DIFFERENT LEVELS OF WATER HYACINTH ON PERFORMANCE OF GROWING RABBITS
}

\author{
T. M. M. Hassan, M. M. Abdella, G. A. El-Sayaad and R. Z. A. Kelyni \\ Department of Animal Production, Faculty of Agriculture, Banha University, Egypt. \\ Tamer.Mohamed@fagr.bu.edu.eg
}

(Received 9/4/2015, accepted 30/5/2015)

\section{SUMMARY}

$\mathrm{T}$

his experiment was carried out at a private rabbit farm under supervision of Banha University Animal Feed Professors duration time from May to July 2014 on 48New Zealand white young male rabbits at 6 weeks of age and about 675 to 717 grams live body weight were divided into four groups (each group contains 12 male rabbits and three replicates) to investigate the effect of feeding different levels of dried water hyacinth leaves and stems $(0,25,50,75 \%$ of Egyptian clover Hay) on rabbits growth and digestibility during 8 weeks of experiment. The results showed non-significant effects on rabbits live body weight and feed intake during 8 weeks of experiment for different levels of water hyacinth. Best final body weight in control group followed by second group, third group and first group of rabbits were 2045 , 2008, 1938 and 1896 grams, respectively. Rabbits average daily weight gain, feed conversion and economical feed efficiency during all experiment duration showed a significant $(\mathrm{P}<0.05)$ different between feeding groups. Highly daily gain in control group followed by second group, third group and first group of rabbits were 24.62, 23.08, 22.13 and 20.56 grams, respectively. Rabbits of the second feeding group (feeding $25 \%$ water hyacinth) gave the significant worst average feed conversion (3.56 feed/gain), while control group recorded the best one (3.06 feed/gain). Present results conclude that, dried water hyacinth leaves and stems may be used as a feed for rabbits to replace $50 \%$ water hyacinth of clover hay in concentrate feed mixture without negative effect on rabbits growth, feed conversion, economic efficiency and digestibility.

Keywords: water hyacinth, rabbits, feed conversion, economic efficiency and digestibility.

\section{INTRODUCTION}

Animal feed stuffs shortage is the most important problem in animal production therefore, a new feed stuffs are required to solve this problem. Water hyacinth $(\mathrm{WH})$ was one of these new feedstuffs, to replace apart of animal feed to solve this problem shortage of animal feed. Animal feed prices have increased yearly therefore; efforts to find more economical nutrient sources less competitive with human feedstuffs have been intensified. Using of such non-traditional feed as water hyacinth in animal feeding substantially participates in solving this problem decreases the cost of feeding and hence the marketing price of animal products (Zewil et al., 1993). Rabbit is suitable to raise for meat production due to its high feed conversion efficiency, rabbits use protein more efficiently than broilers and up to $20 \%$ roughage can be included in their diet. Water hyacinth, an aquatic weed that grows widely in irrigation and drainage canals in Egypt, was successfully used in partial substitution of hay in rabbit's diets (Eleraky and Mohamed, 1996). The main constraint for using water hyacinth in animal feeding was its low feed intake, due to its content of unpalatable substances such as tannins, nitrates and oxalates. The pressing and extraction of water hyacinth showed satisfactory results for both extracted protein and fibrous residues. This satisfactory results my due to the elimination of part of these unpalatable substances throughout pressing and extraction (El-Adawey et al., 2000).

The objectives of this study to investigate effect of replacing Egyptian clover (Trifolium alexandriunm) hay by dried water hyacinth leaves and stems on growth performance, feed conversion, economic efficiency and digestibility of growing rabbits in different levels $(0,25,50$ and $75 \%)$ in rabbits diet. 


\section{MATERIAL AND METHODS}

\section{Preparation of water hyacinth:}

Water hyacinth was collected from River Nile in EL-Qalag, Qalyubia and separated leaves and stems from roots of plants to sun drying for 20 days and flipping the plants every three days. Dried water hyacinth leaves and stems was chopped to replace Egyptian clover hay in concentrate feeding mixture and added to rabbit's diet in different levels $(0,25,50$ and $75 \%)$. Chemical composition of water hyacinth and the experimental diets are presented in Table (1).

Table (1): Chemical composition of water hyacinth and the experimental diets.

\begin{tabular}{lcccccc}
\hline \multirow{2}{*}{ Item } & \multicolumn{5}{c}{ Composition on DM basis \% } \\
\cline { 2 - 6 } & DM & CP & EE & NFE & CF & Ash \\
\cline { 2 - 6 } Sun dried water hyacinth & 91.4 & 14.7 & 2.1 & 31.6 & 22.7 & 28.9 \\
CFM (Control group)* & 91.1 & 16.1 & 4.3 & 61.0 & 14.2 & 4.4 \\
$1^{\text {st }}$ group (25\% water hyacinth) & 91.1 & 16.3 & 4.2 & 60.4 & 14.5 & 4.6 \\
$2^{\text {nd }}$ group (50\% water hyacinth) & 91.1 & 16.6 & 4.2 & 59.5 & 14.7 & 5.0 \\
$3^{\text {rd }}$ groups (75\% water hyacinth) & 91.0 & 16.4 & 4.1 & 50.1 & 15.1 & 5.3 \\
\hline
\end{tabular}

*CFM consisted of Hay $30 \%$, Barley $9 \%$, corn Yellow $15 \%$, wheat, bran $30 \%$, soybean meal $14 \%$

and add nitration $2 \%$.

\section{Experimental rabbits and feeding groups:}

Forty eight New Zealand White young male rabbits at 6 weeks of age at about 696 grams average live body weight were divided into four groups (each group contains 12 male rabbits and three replicates). The control group was fed on the normal diet according to NRC (2004) recommendations. Water hyacinth was used to be replacing 25, 50 and $75 \%$ of Egyptian clover hay in concentrate feeding mixture diet, for 1 st, 2 nd and 3rd group, respectively.

Table (2): Feed ingredients of the experimental diets.

\begin{tabular}{|c|c|c|c|c|c|}
\hline \multirow{2}{*}{\multicolumn{2}{|c|}{ Ingredients $\%$}} & \multicolumn{4}{|c|}{ Experimental diets } \\
\hline & & $\begin{array}{l}\text { Control } \\
\text { group }\end{array}$ & $1^{\text {st }}$ group $(25 \%)$ & $2^{\text {nd }}$ group (50\%) & $3^{\text {rd }}$ groups $(75 \%)$ \\
\hline Egyptian clover hay & & 30 & 22.5 & 15 & 7.5 \\
\hline Water hyacinth & & 0 & 7.5 & 15 & 22.5 \\
\hline Yellow corn & & 15 & 15 & 15 & 15 \\
\hline Wheat brain & & 30 & 30 & 30 & 30 \\
\hline $\begin{array}{l}\text { Soybean meal } \\
\text { protein) }\end{array}$ & $(48 \%$ & 14 & 14 & 14 & 14 \\
\hline Barley & & 9 & 9 & 9 & 9 \\
\hline Common salt & & 0.5 & 0.5 & 0.5 & 0.5 \\
\hline Lime stone & & 0.78 & 0.78 & 0.78 & 0.78 \\
\hline Mineral premix & & 0.6 & 0.6 & 0.6 & 0.6 \\
\hline Anti-toxins and fungi & & 0.12 & 0.12 & 0.12 & 0.12 \\
\hline Total & & 100 & 100 & 100 & 100 \\
\hline
\end{tabular}

All rabbits in each group were individually weighed to the nearest gram at the start of the feeding period (6weeks of age) and then weekly in the morning before feeding and drinking till the end of feeding period (14 weeks of age). Diets were offered twice daily in equal quantities at the 8 am and $4 \mathrm{pm}$ and estimated for each of the four groups every day. Both of consumed diets and refusals (if any) were recorded daily.

Average daily gain, feed conversion and economic efficiency were estimated as follows:

Average daily weight gain = total gain $($ gram $) /$ number of days of feeding period 
Feed conversion $=$ feed intake $($ grams $) /$ gain in weight $($ grams $)$

Economic efficiency $=$ price of weight gain $(\mathrm{LE}) /$ cost of feed consumed $(\mathrm{LE})$

\section{Digestibility trial:}

At the end of the experimental period a digestibility trail (4 rabbits in each group) with 7 days collection period. Tow rabbits with collar to prevent coprophage were used in each group. Rabbits were housed individually in metabolic cages to facilitate the quantitative collection of feces throughout the digestibility trail. Feces of each rabbit were collected and feed intake was recorded every day in the morning during the collection period (7 days). Fecal samples for each rabbit all collected for each male it stored (by draying in $60^{\circ} \mathrm{C}$ for 72 hours) for chemical analysis according to AOAC (1990).

\section{Statistical analysis:}

Statistical analysis was carried out by using the least squares procedure for analyzing the data with unequal sub class number described by SAS (2004).

The statistical model was used as follows:

Model (1) body weight, average daily gain, feed intake, feed conversion and economic efficiency

$$
Y i j k=\mu+T i+R j+(T R) i j+e i j k
$$

Where:

Yijk = the observation of growth performance for ijk rabbit;

$\mu=$ general mean, common element to all observations;

$\mathrm{Ti}=$ the fixed effect due to $\mathrm{I}$ th feeding group $(\mathrm{i}=1,2,3,4)$;

$\mathrm{Rj}=$ the fixed effect due to the $\mathrm{j}$ th replicate $(\mathrm{j}=1,2,3)$;

(TR)ij= the fixed effect of the interaction between feeding group and replicate;

eijk $=$ random error associated with the individual observation and assumed $(\mathrm{NI} D) \cong(0, \sigma 2 \mathrm{e})$.

Model (2) rabbits digestion coefficient.

$$
Y i j k=\mu+T i+C j+(T C) i j+e i j k
$$

Where:

Yijk= the observation of digestion coefficients in feeding rabbit; $\mu=$ general mean, common element to all observations;

$\mathrm{Ti}=$ the fixed effect due to I th coprophage status $(\mathrm{i}=1,2)$;

$\mathrm{C}=$ the fixed effect due to the $\mathrm{j}$ th replicate $(\mathrm{j}=1,2,3)$;

(TC)ij = the fixed effect of the interaction between feeding group and coprophage status;

eijk= random error associated with the individual observation and assumed (NI D) $\cong(0, \sigma 2 e)$.

Tests of significance for differences between means were carried out according to Duncan (1955).

\section{RESULTS AND DISCUSSION}

\section{Growth performance:}

The least squares means and standard errors of the studied measures are presented in Table (3). The highest final body weight (2045grams) was recorded for the control group followed by the $50 \% \mathrm{WH}$ while, the lowest one was recorded for the $25 \% \mathrm{WH}$ group (1896 grams). The differences in final body weight due to feeding treatment effect were not significant at all levels of water hyacinth. These results agree with those observed by Moreland and Collins (1990) who recorded that differences in rabbit body weights failed to reject the null hypothesis that the growth rate was equivalent for 20 and $30 \%$ water hyacinth diets. On the other hand, Van Thu and Kim Dong (2009) showed that rabbits final live body weight was $2.012,2.020,2.059,2.011,1.827$ and 1.695 grams, for rabbits that fed water hyacinth at levels of $0,20,40,60,80$ and $100 \%$ replacement to Para-grass (dry matter basis). The same authors 


\section{Hassan et al.}

found that live body weight affected significantly $(\mathrm{P}<0.05)$ by different levels of water hyacinth in rabbit's diet.

Average daily weight gain at all feeding duration weeks (8weeks) had the same trend as these of final body weight. The control group was the significant heavier average daily weight gain $(24.62 \mathrm{~g})$, followed by the second $(23.08 \mathrm{~g})$, third $(22.13 \mathrm{~g})$ and then the first $(20.56 \mathrm{~g})$ experimental group. Differences between average daily weight gains due to water hyacinth levels in rabbit's diet were significant $(\mathrm{P}<0.05)$ as shown in Table (3). These results agree with those Zeweil et al., (1993) recorded a significant $(\mathrm{P}<0.05)$ differences between daily weight gain of rabbits fed on water hyacinth leaves in different levels $0,10,20$ and $30 \%$ was $19.44,20.16,17.40$ and 19.94 grams, respectively.

Rabbits of all feeding groups almost had the same total feed intake during the feeding duration and there were no significant differences between groups due to feeding levels of water hyacinth as observed in Table (3). These results are in accordance with those shown by Eleraky and Mohamed (1996) who reported that rabbits total feed consumption was 5422, 5513. And 5226 grams, for animal fed 0, 15 and $30 \%$ water hyacinth, respectively. Differences between feeding levels groups were not significantly. Zeweil et al., (1993) recorded that rabbits feed intake of water hyacinth levels 0, 10, 20 and 30\% were 85.6, 89.68, 93.09, and 81.6 grams/day, respectively without significant differences.

Table (3): Least-squares means and standard errors $(\mathrm{LSM} \pm \mathrm{SE})$ of rabbit's growth performance.

\begin{tabular}{|c|c|c|c|c|c|}
\hline Item & Control group & $\begin{array}{l}\text { First group } \\
(25 \% \mathrm{WH})\end{array}$ & $\begin{array}{c}\text { Second group } \\
(50 \% \mathrm{WH})\end{array}$ & $\begin{array}{l}\text { Third group } \\
(75 \% \mathrm{WH})\end{array}$ & Sig \\
\hline No. of rabbits & 12 & 12 & 12 & 12 & \\
\hline $\begin{array}{l}\text { Initial body } \\
\text { weight }(\mathrm{g})\end{array}$ & $675.41 \pm 36.37$ & $717.50 \pm 36.37$ & $715.83 \pm 36.37$ & $699.16 \pm 36.37$ & ns \\
\hline $\begin{array}{l}\text { Final body } \\
\text { weight }(g)\end{array}$ & $2045.16 \pm 65.77$ & $1896.16 \pm 65.77$ & $2008.75 \pm 65.77$ & $1938.75 \pm 65.77$ & ns \\
\hline $\begin{array}{l}\text { Average daily } \\
\text { gain }(\mathrm{g})\end{array}$ & $24.62 \pm .95 \mathrm{a}$ & $20.56 \pm .95 b$ & $23.08 \pm .95 \mathrm{ab}$ & $22.13 \pm .95 a b$ & $*$ \\
\hline $\begin{array}{l}\text { Daily feed intake } \\
\text { of dry matter }(\mathrm{g})\end{array}$ & $73.54 \pm 1.79$ & $72.80 \pm 1.79$ & $78.73 \pm 1.79$ & $73.94 \pm 1.79$ & ns \\
\hline $\begin{array}{l}\text { Total feed intake } \\
\text { of dry matter }(\mathrm{g})\end{array}$ & $4118.33 \pm 100.38$ & $4076.83 \pm 100.38$ & $4409.41 \pm 100.38$ & $4141.00 \pm 100.38$ & ns \\
\hline $\begin{array}{l}\text { Feed conversion } \\
\text { (feed/gain) }\end{array}$ & $3.06 \pm 0.13 b$ & $3.56 \pm 0.13 \mathrm{a}$ & $3.48 \pm 0.13 \mathrm{a}$ & $3.38 \pm 0.13 \mathrm{ab}$ & $*$ \\
\hline $\begin{array}{l}\text { Economical feed } \\
\text { efficiency } \\
\text { (Benefit/cost } \\
\text { ratio) }\end{array}$ & $2.99 \pm 0.11 \mathrm{ab}$ & $2.67 \pm 0.11 b$ & $2.91 \pm 0.11 \mathrm{ab}$ & $3.12 \pm 0.11 \mathrm{a}$ & $*$ \\
\hline
\end{tabular}

Rabbits of the first feeding group (feeding $25 \%$ water hyacinth) gave the significant worst average feed conversion (3.56 feed/gain), while control group recorded the best one (3.06 feed/gain). The differences between means of rabbits feed conversion, due to feeding groups effect, were significant $(\mathrm{P}<0.05)$. These results are in good agreement with those of Van Thu and Kim Dong (2009) who recorded that feed conversion rates in growing rabbits fed on $0,20,40,60,80$ and $100 \%$ water hyacinth were $3.75,3.68$, $3.63,3.76,4.37$ and $4.25 \mathrm{DM} / \mathrm{kg}$ live body weight, respectively, with significant differences. Zeweil et al., (1993) found that feed conversion ratio was 4.40; 4.45, 5.27 and 8.22, for rabbits fed on 0, 10, 20 and $30 \%$ water hyacinth in diet. Differences between treatments were statistically significant $(\mathrm{P}>0.05)$.

Third feeding group of rabbits (75\%water hyacinth) had the significant highest economical feed efficiency value (3.12) followed by control group (2.99), second group (2.91) and then the first group (2.67). The differences between means of economical feed efficiency, due to feeding groups effect, were significant $(\mathrm{P}<0.05)$. These results are near to that obtained by Van Thu and Kim Dong (2009) who studied the effect of feeding rabbits different water hyacinth levels; found that economic returns were similar with the highest value of treatment was 24.52, 24.62, 26.27, 24.40, 16.81 and 13.26, for rabbits fed on $0,20,40,60,80$ and $100 \%$ water hyacinth, respectively. El-Adawy et al., (2000) reported that economic efficiency of feeding growing rabbits on water hyacinth instead of alfalfa hay was 186.36, 197.4 and 190.01gain cost/feed cost, for rabbits fed on 0, 18 and $36 \%$ water hyacinth, respectively. The 
same authors concluded that feeding growing rabbits from 7-15 weeks of age on diets containing 18 and $36 \%$ water hyacinth decreased the feed cost by 8.37 and $14.99 \%$ and increased the economic efficiency by 5.9 and $1.9 \%$, respectively.

\section{Digestibility trial:}

It is of interest to notice that the digestibility coefficient of $\mathrm{OM}, \mathrm{CP}, \mathrm{CF}$ and $\mathrm{EE}$ between the different experimental groups were not significant. However, significant differences were recorded for EE digestibility. These results agree with those of many investigators; El-Adawy et al., (2000) observed no significant differences in the digestibility coefficients of nutrients among rabbits fed the control diet and rabbits fed diets containing 18 and $36 \%$ water hyacinth instead of alfalfa hay. Zewil et al., (1993) reported that digestibility of protein and fat were similar in the rabbits given no water hyacinth leaves or $10 \%$ water hyacinth leaves, digestibility of nitrogen free extract was not significantly different among groups but the digestibility of crude fiber increased with increasing level water hyacinth leaves in the diet.

Table (4): Least square means and standard errors ( $L S M \pm S E)$ of rabbits' digestion coefficients.

\begin{tabular}{|c|c|c|c|c|c|c|}
\hline Item & No. & OM & $\mathrm{CP}$ & $\mathrm{CF}$ & $\mathrm{EE}$ & NFE \\
\hline Control group & 4 & $64.00 \pm 0.54$ & $64.25 \pm 0.66$ & $17.25 \pm 0.51$ & $74.75 \pm 0.46 b$ & $66.75 \pm 0.62$ \\
\hline $\begin{array}{l}1^{\text {st }} \text { group ( } 25 \% \\
\text { water hyacinth) }\end{array}$ & 4 & $63.00 \pm 0.54$ & $65.50 \pm 0.66$ & $17.25 \pm 0.51$ & $76.00 \pm 0.46 \mathrm{ab}$ & $66.75 \pm 0.62$ \\
\hline $\begin{array}{l}2^{\text {nd }} \text { group }(50 \% \\
\text { water hyacinth) }\end{array}$ & 4 & $62.25 \pm 0.54$ & $66.00 \pm 0.66$ & $18.25 \pm 0.51$ & $76.75 \pm 0.46 \mathrm{a}$ & $66.25 \pm 0.62$ \\
\hline $\begin{array}{l}3^{\text {rd }} \text { groups }(75 \% \\
\text { water hyacinth) }\end{array}$ & 4 & $62.50 \pm 0.54$ & $66.75 \pm 0.66$ & $18.50 \pm 0.51$ & $77.00 \pm 0.46 \mathrm{a}$ & $67.50 \pm 0.62$ \\
\hline $\begin{array}{l}\text { Significant } \\
\text { Coprophagy status: }\end{array}$ & & $\mathrm{ns}$ & ns & ns & $*$ & ns \\
\hline Collared rabbits & 8 & $61.25 \pm 0.38 b$ & $62.12 \pm 0.46 b$ & $16.12 \pm 0.36 b$ & $74.25 \pm 0.33 b$ & $64.50 \pm 0.44 b$ \\
\hline $\begin{array}{l}\text { Uncollared rabbits } \\
\text { Significant }\end{array}$ & 8 & $\begin{array}{c}64.62 \pm 0.38 \mathrm{a} \\
* * *\end{array}$ & $\begin{array}{c}68.37 \pm 0.46 \mathrm{a} \\
* * *\end{array}$ & $\begin{array}{c}19.50 \pm 0.36 \mathrm{a} \\
* * *\end{array}$ & $\begin{array}{c}78.50 \pm 0.33 \mathrm{a} \\
* * *\end{array}$ & $\begin{array}{c}69.12 \pm 0.44 \mathrm{a} \\
* * *\end{array}$ \\
\hline
\end{tabular}

Un-collared rabbit feeding group had higher digestion co-efficient of organic matter, crude protein, crude fiber, ether extract and nitrogen free extract than collared rabbit feeding group. The differences between means of digestion co-efficient, due to coprophagy status of feeding rabbits groups, were highly significant for organic matter, crude protein, crude fiber, ether extract and nitrogen free extract $(\mathrm{P}<0.001)$ (Table 4). The differences among uncollared and collared rabbits due to prevention of coprophagy status were significant $(\mathrm{P}<0.05)$. These results indicate that the prevention of coprophagy in rabbits decreased the digestibility of all nutrients. This presented results almost agree with those of Ibrahim (2005) found that digestibility values of all nutrients (OM, CP, CF, EE and NFE) for uncolored rabbits were higher than those for collared ones.

\section{CONCLUSION}

Present results conclude that, sun dried water hyacinth leaves and stems may be used as a feed for rabbits to replace $50 \%$ water hyacinth of clover hay in concentrate feed mixture without negative effect on rabbits growth, feed conversion, economic efficiency and digestibility, in addition to it reduce the cost of rabbits feed and pollution of environment.

\section{REFERENCES}

AOAC (1990). Official Methods of Analysis. 15th Association of Official Analytical Chemists Washington, D. C. 


\section{Hassan et al.}

Duncan, D.B. (1955). Multiple ranges and multiple F-test. Biometrics 11: 1-42.

El-Adawy, M.M.; B.E. Borhami and A.E.Y. Abdel-Hamid (2000). Utilization of sugar beet pulp and fibrous residues of berseem and water hyacinth in feeding growing New Zealand White rabbits. Egyptian Journal of Rabbit Science, 10(1): 1-17.

Eleraky, W.A. and W.E. Mohamed (1996). Growth performance, carcass traits and some related physiological changes of growing rabbits fed on acacia and water hyacinth. Egyptian Journal of Rabbit Science; 6 (1):87-98. 32.

Ibrahim, W.A.E. (2005). Inclusion of some wastes in rabbits diets. M.Sc., Faculty of Agriculture, AlAzhar University, Cairo, Egypt.

Manh, H.L.; N.N.X. Dung; S. Yamasaki and R. Takada (2002). Replacement of concentrate by water hyacinth (Eichhroriacrassipes): Effects on digestibility, feed intake and live weight gain in pig production. Proceedings of the annual workshop of JIRCAS Mekong Delta Project - Development of new technologies and their practice for sustainable farming systems in the Mekong Delta; November 26-28, 2002, Can Tho University, Vietnam. p. 152-158

Moreland, A.F. and B.R. Collins (1990). Water hyacinth (Eichhoraniacrassipes) grown in municipal waste water as source of organic matter in rabbit food. Journal of Aquatic Plant Management, 26:1-13.

NRC (2004). National Research Council: Nutrient requirements of sheep, (9th Ed.) National Academy Press, Washington, D.C.

SAS (2004). SAS Procedure Guide" version 9 Ed”. SAS Institute Inc., Cary, NS, USA.

Van Thu, N. and N.T. Kim Dong (2009). A study of water hyacinth (Eichhorniacraszsipes L.) as a feed resource for feeding growing rabbits. International Conference on Livestock, Climate change and the Environment. A GiangUniversity, Vietnam, p.16-18.

Xuan Men, B. and T.T. Thuy Hang (2010). Use of Tra-fish by-products and water hyacinth as replacements for protein, minerals and vitamins in diets of laying ducks raised in a biosecure duckfish system on smallholdings in the Mekong Delta. Cantho University, Vietnam.

Zeweil, H.S.; A.H. Nour and S.A. Abd El-Rahman (1993). Use of water hyacinth (Eichhorniacrassipes mart sloms) in rabbit feeding. Egyptian Journal of Rabbit Science; 3(2):191-198. 13.
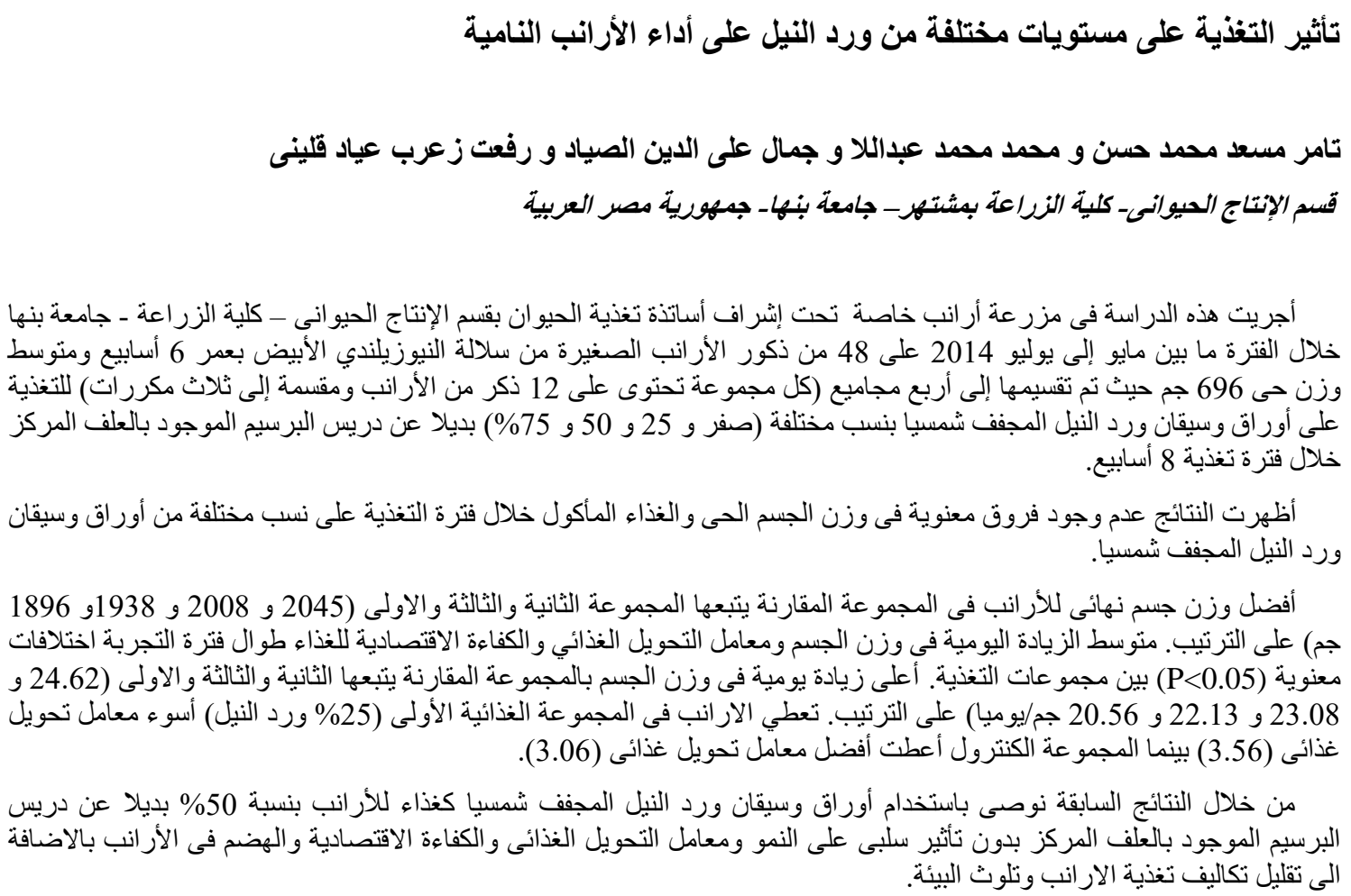